\title{
MENGENAL MARKETING DAN MARKETERS SYARIAH
}

\author{
Ahmad Miftah \\ STIE Bina Bangsa, Serang - Banten
}

\begin{abstract}
Abstrak. Mengenal Marketing dan Marketers Syariah. Bagi dunia bisnis yang berorientasi profit termasuk lingkup bisnis syariah yang mengarah kepada falah dan profit oriented, kegiatan pemasaran (marketing) merupakan suatu kebutuhan utama dan menjadi suatu keharusan.Oleh karena itu dunia bisnis perlu untuk mengemas kegiatan pemasarannya secara terpadu dan terus menerus untuk melakukan riset pasar. Pemasaran harus dikelola secara profesional sehingga kebutuhan dan keinginan konsumen akan segera terpenuhi dan terwujud. Strategi pemasaran yang efisien harus dapat memberikan gambaran yang jelas dan terarah tentang apa yang dilakukan oleh marketers dalam menggunakan setiap kesempatan atau peluang pada beberapa sasaran pemasaran usaha bisnis syariah.
\end{abstract}

Kata Kunci: Marketing, Marketer.

\section{Latar Belakang}

Dalam pengelolaan bisnis termasuk bisnis yang menerapkan prinsip syariah, memerlukan kinerja marketing. Marketing adalah front (garda) depan dari suatu bisnis. Marketing memiliki definisi kerja dari suatu proses bisnis sehingga mencapai produk dan nilai-nilai produk tersebut kepada konsumen.

Marketing dalam dunia bisnis bukan merupakan suatu konsep yang hanya mengandalkan instrumen seperti marketing mix, targeting, positioning serta branding semata. Namun marketing telah jauh berkembang kearah yang lebih dewasa dan tumbuh seperti new wave marketing ${ }^{1}$.

Dengan demikian dalam memasarkan sebuah produk, peran dari seluruh stakeholder perusahaan dalam hal ini adalah marketing sangat diperlukan. Dibutuhkan kemampuan maksimal dalam hal ini adalah strategi pemasaran yang baik sehingga suatu unit bisnis dapat meningkatkan laba operasional. 
Islamiconomic: Jurnal Ekonomi Islam

Vol.6 No.2 Juli - Desember 2015

\section{Marketing Syariah}

Kata pemasaran dalam bahasa inggris disebut marketing. Pemasaran (marketing) adalah suatu sistem keseluruhan dari kegiatan bisnis yang ditujukan untuk merencanakan, menentukan harga, mempromosikan dan mendistribusikan barang dan jasa yang memuaskan kebutuhan baik kepada nasabah yang ada maupun nasabah potensial.

Pemasaran harus dijalankan secara powerfull sehingga kebutuhan dan keinginan konsumen akan dapat dilayani dan dipenuhi dengan baik. Pengelolaan pemasaran yang profesional merupakan suatu hal yang wajib di laksanakan dalam iklim usaha bisnis. Pemasaran bertujuan untuk dapat merebut hati konsumen sehingga peranannya sebagai connected dapat berjalan dengan baik ${ }^{2}$. Penyediaan keinginan dan kebutuhan konsumen harus dilakukan melalui kegiatan pemasaran sehingga diharapkan dapat memenuhi kebutuhan dan keinginan serta kepuasan konsumen.

Pemasaran didalam literatur fiqih Islam disebutkan wakalah atau perwakilan. Wakalah atau wikalah yang berarti penyerahan, pendelegasian atau pemberian mandat. Wakalah dapat juga diartikan sebagai penyerahan dari seseorang yang dapat dilakukan oleh individu atau dapat diwakilkan kepada orang lain. ${ }^{3}$

Marketing syariah diartikan sebagai suatu disiplin unit bisnis strategis yang diarahkan kepada suatu proses dimana terdapat perubahan nilai serta penawaran dari satu penggagas kepada bagian yang lain dalam keseluruhannya sesuai dengan prinsip-prinsip kegiatan muamalah dalam Islam.

Hukum pemasaran (wakalah) dalam landasan ijma adalah sunnah, dikarenakan terdapat nilai-nilai yang mengandung unsur-unsur yang teramat mulia (ta'awun) yang didasarkan atas kebaikan dan taqwa.

Didalam landasan fiqih segala sesuatu yang berkaitan dengan muamalah dapat dilakukan selama tidak ada suatu dalil pun yang mengharamkannya. Rukun wakalah terdiri dari 3 (tiga) rukun yang merupakan komponen persyaratan dalam melakukan jual-beli, yaitu: terdapat penjual dan pembeli, terdapat barang/ produk/ jasa serta terdapat ijab qabul. 
Ahmad Miftah:Mengenal Marketing dan...

\section{Tujuan Marketing Syariah}

Secara umum tujuan marketing syariah adalah:

1. Memudahkan konsumen untuk membeli produk yang ditawarkan secara berulang-ulang.

2. Memaksimalkan kepuasan konsumen melalui berbagai pelayanan yang diinginkan.

3. Memaksimumkan pilihan (diversifikasi produk) dalam arti perusahaan menyediakan berbagai jenis produk sehingga konsumen memiliki beragam pilihan.

4. Memaksimalkan kualitas dengan memberikan berbagai kemudahan kepada konsumen.

\section{Konsep Marketing Syariah}

Berdasarkan pada pandangan bahwa tugas marketing adalah menentukan kebutuhan konsumen, kekurangan dan minat segmen pasar, maka untuk dapat memenuhi kepuasan/keinginan itu secara efektif dan secara efisien dibanding pesaing dilakukan dengan cara memelihara hubungan yang baik dan intens dengan konsumen.

Konsep pemasaran syariah menekankan bahwa perlunya menerapkan manajemen profesional, artinya dengan melakukan kegiatan tersebut maka semua produk atau jasa yang dihasilkan pasti dapat memiliki positioning tersendiri. Kompetitor bukanlah merupakan suatu penghalang yang harus ditakuti atau dimusuhi. $^{4}$

Kompetitor dapat dijadikan sebagai sumber motivasi untuk dapat memperbaiki kinerja marketing. Pesaing dapat mendorong pihak perusahaan dalam hal ini adalah marketers untuk dapat bekerja lebih kreatif dalam memasarkan produk berupa barang maupun jasa.

Hal inilah yang dapat membedakan antara marketing bisnis perusahaan konvensional dengan marketing bisnis yang menerapkan prinsip syariah yang 
Islamiconomic: Jurnal Ekonomi Islam Vol.6 No.2 Juli - Desember 2015

memberikan kepuasan kepada konsumen dan stakeholders tidak saja pada tataran kepuasan duniawi, akan tetapi juga mengarah pada kepuasan ukhrawi, karena terdapat ridha Allah SWT yang dituju. Dari hal tersebut dapat diketahui bahwa tujuan marketing bisnis dengan prinsip syariah adalah dengan penerapan prinsip-prinsip etika atau berlandaskan kepada entitas nilai-nilai Islam sebagai penciptaan kepuasan duniawi dan ukhrawi bagi para stakeholders perusahaan.

\section{Profil Marketers Syariah}

Suatu kegiatan unit bisnis akan tetap dikatakan bisnis, adanya pemisahan antara entitas bisnis syariah dan bisnis konvensional terjadi akibat adanya gejala pencampuran pelalaian atau bahkan pelanggaran norma atau etika Islami, terutama bagi pelaku bisnis muslim dan gejala tersebut juga terjadi pada pola perilaku pembelian atau konsumsi yang juga seharusnya beretika Islami.

Gejala pelalaian dan pelanggaran norma serta etika Islami tersebut secara perlahan-lahan terakumulasi menjadi hal yang umum dan biasa dan bahkan semakin membesar. Pada suatu kesimpulan terdapat regulasi ekonomi bisnis yang memiliki kecendrungan tidak memiliki etika serta nilai-nilai Islam. Hal tersebut, bisa saja terjadi karena lingkungan masyarakat yang beragam/ majemuk.

Dari gejala serta kejadian tersebut, akhirnya munculah kesadaran serta kebangkitan untuk menuju kepada arah ekonomi yang memiliki karakteristik nilai Islami atau tepatnya menerapkan bisnis syariah/ sistem syariah.

Dalam pengelolaan bisnis tersebut, termasuk yang menerapkan prinsip syariah memerlukan kerja seorang marketers. Karena marketers dapat diibaratkan sebagai seseorang yang menjembatani antara konsumen dan perusahaan. Seorang marketers harus dapat memiliki karakter kebersihan jiwa dan bersikap sustainibility penjagaan kebersihan jiwa. Dengan kata lain marketers harus mempunyai "soul" yang terbentuk, hal tersebut dikarenakan bahwa lingkungan bisnis yang berlaku saat ini memiliki rutinitas serta goncangan yang sangat besar atas semua persaingan bisnis tanpa memperhatikan aspek nilai-nilai religiusitas. 
Ahmad Miftah:Mengenal Marketing dan...

\section{Membangun Karakter Syariah Pada Marketers}

Karakter syariah pada marketers harus dibangun dan dikembangkan dalam rangka meningkatkan kinerja marketing yang berbasis pada pola pengembangan karakter jiwa positifdan berpegang pada prinsip syariah atau aturan-aturan yang telah ditetapkan dalam Islam untuk menuju kepada ke-ridha-an Allah SWT.

Marketers yang berupaya mencari ke-ridha-an Allah SWT, akan memunculkan keikhlasan yang berdampak pada kerja dan kinerja yang sepenuh jiwa dalam melayani konsumen. Selanjutnya marketers tersebut pun akan lebih realistis bila dibandingkan dengan kerja pemasaran secara optimal serta maksimal untuk tidak mengindahkan nilai atau prinsip syariah. Dengan kata lain marketers syariah akan lebih memperhitungkan kepuasan serta keuntungan pada kehidupan pasca duniawi.

\section{Kesimpulan}

Marketers syariah harus dapat mengembangkan karakter humanistik agar memiliki keseimbangan (balancing) hubungan antara sesama manusia. Dalam kerja seorang marketers pun aspek humanistik tersebut harus dapat diimplementasikan dalam penghargaan untuk memuliakan manusia, bukan hanya saja mempelajari karakteristik manusia untuk dapat mempengaruhi konsumen untuk melakukan perilaku konsumerisme yang tidak normati serta realistis.

Untuk dapat membangun karakter jiwa marketers yang sesuai dengan syariah, diperlukan pembangunan keikhlasan serta self development untuk melakukan entitas bisnis halal. Marketers syariah harus membangun dirinya dengan berbagai macam karakter seperti memiliki kepribadian spiritual (taqwa), jujur dan dapat dipercaya (amanah) serta tidak melakukan sogok (tidak riswah).

\section{Pustaka Acuan}

Hermawan Kartajaya, Connect! Surving New Wave Marketing, Jakarta: Gramedia, 2010 Irawan, Strategi Pemasaran Syariah, Jakarta: Grasindo, 2005 Masyarakat Ekonomi Syariah (MES) Pekalongan, Ekonomi Syariah (Konsep, Praktek \& Penguatan Kelembagaannya), Semarang: Pustaka Rizki Putra, 2009 
Islamiconomic: Jurnal Ekonomi Islam Vol.6 No.2 Juli - Desember 2015

Philip Kotler, Manajemen Pemasaran, Prentice Hall

\section{Catatan Akhir:}

${ }^{1}$ Hermawan Kartajaya, Connect! Surving New Wave Marketing, Jakarta: Gramedia, 2010

2 Philip Kotler, Manajemen Pemasaran, Prentice Hall

${ }^{3}$ Irawan, Strategi Pemasaran Syariah, Jakarta: Grasindo, 2005

${ }^{4}$ Masyarakat Ekonomi Syariah (MES) Pekalongan, Ekonomi Syariah (Konsep, Praktek \& Penguatan

Kelembagaannya), Semarang: Pustaka Rizki Putra, 2009 